\title{
Limitations to Productivity of Some Ultisol and Oxisol Subsoils ${ }^{1,2}$
}

\author{
K. Dale Ritchey and Richard H. Fox ${ }^{3}$
}

\section{INTRODUCTION}

As population and agricultural land use pressure increase, both erosion and land leveling expose more subsoil to potential cultivation. Subsoils are often thought of as being irremediably inferior to surface soils. In the fight to increase world food production it is important to know where the real limitations to production lie, and accordingly this study undertook to investigate what limits exist to subsoil fertility in the Humid Tropics.

Reported instances of cases where subsoil productivity is lower than the productivity of the surface soil include that of Abruña and co-workers (1) who found in Puerto Rico plot experiments that tobacco yields on Corozal subsoil (Aquic Tropudult) were at least 23 percent lower than those on Corozal clay surface soil at comparable base saturations and rates of applied fertilizer.

Pangola grass growing on Alonso clay (Orthoxic Tropohumult) subsoil at Adjuntas gave a yield of 75 percent of that obtained on the surface soil (F. Abruña, personal communication).

A Coto subsoil (Tropeptic Haplorthox) at Isabela, although exposed for many years, remained practically barren. The infertility of the subsoil was apparently due to $\mathrm{Zn}$ deficiency. Maize plants not sprayed with zinc sulfate stopped growing after reaching a height of $30 \mathrm{~cm}$, while $\mathrm{Zn}$ sprayed plants in the next row matured normally (4).

In greenhouse tests on Carreras surface and subsoil (a Typic Tropohumult formerly called Humatas), and Cialitos surface and subsoil (Orthoxic Tropohumult), the dry weights of bean tops grown on the surface

${ }^{1}$ Manuscript submitted to Editorial Board June 13, 1973.

2 Cornell University Agronomy Paper No. 1042. This study was part of the work supported by the U.S. Agency for International Development under grant CSD2834 and research contract CSD-2490 entitled: Soil Fertility Requirements to Attain Efficient Production of Food Crops on the Extensive, Deep, Well-Drained but Relatively Infertile Soils of the Humid Tropics.

- Formerly Graduate Research Assistant, Cornell University, now Soil Fertility Specialist, University of Wisconsin, Madison, Wisconsin; and Assistant Professor of Soil Science, Cornell University, Ithaca, New York, respectively. The authors wish to extend their gratitude to the staff of the Agricultural Experiment Station, College of Agricultural Sciences, Mayagüez Campus, University of Puerto Rico, Río Piedras, P.R., where the study was carried out. 
soils were twice those grown on the subsoils with complete fertilization including micronutrients (3).

Lathwell et al. (9) studied the nitrogen-supplying potential of 10 tropical Ultisols and Oxisols from Puerto Rico. After fertilizing with $\mathrm{N}, \mathrm{P}, \mathrm{K}, \mathrm{Mg}$ and micronutrients, the greenhouse yield for five crops of corn and sorghum on the least productive soil, Nipe (Typic Acrorthox), was 42 percent of that on the most productive, Carreras (Typic Tropohumult); additional experiments indicated these results may have been due to high phosphorus fixing capacity in the Nipe soil (Lathwell, personal communication).

This study was undertaken for the purpose of finding the fertility factors responsible for preventing maximum growth on some Puerto Rican subsoils. In addition to conventional pot watering, a new method of watering which reduces the possibility of moisture stress was used to see if some previously reported depressed pot yields on subsoils could be partially attributed to ineffective conventional pot watering techniques.

\section{GENERAL METHODS}

Soils were collected from experimental plots ${ }^{4}$ near Jayuya (Los Guineos soil series), Manatí (Piña soil series), Barranquitas (Catalina soil series at two field sites), and at the Corozal Substation (Carreras soil series, formerly called Humatas). The sample of the Nipe soil series was collected from Las Mesas near Mayagüez. Surface soils were collected from the plow layer $(0-20 \mathrm{~cm})$ and the subsoils from 20 to $50 \mathrm{~cm}$ depth. The soils are described in tables 1 and 2.

The thoroughly mixed air-dry soils were ground in a Quaker City Mill to $4 \mathrm{~mm}$ or less, mixed with liming materials and fertilizers, and placed in 2,000 and $3,000 \mathrm{ml}$ capacity white plastic pots with 4 holes in the bottom (diameter of pot tops 15 or $20 \mathrm{~cm}$ ). Where density of the soils differed greatly, equal volumes rather than equal weights of soil were used. A layer of fiberglass was used to line the bottoms of the pots.

Modifications of the wick-watering method of Dolar and Keeney (5) were used on a number of pots (Ritchey and Fox (10)). A hole was melted through the bottom of the pot with a red-hot, 1.4-cm diameter iron pipe. A wick was inserted which extended halfway up through the center of the pot and down into a container of water below the pot. A preliminary trial of the method using USP cotton fiber for wicks was made in Experiment

4 These field plots are part of a collaborative soil fertility research project of Cornell University, the University of Puerto Rico Agricultural Experiment Station and the U.S. Department of Agriculture. This project is supported in part by the U.S. Agency for International Development. 
TABLE 1.-Chemical properties of soils used and their classification under the U.S. Soil Taxonomy

\begin{tabular}{|c|c|c|c|c|c|c|c|c|}
\hline Soil & Depth & $\mathrm{pH}^{\mathbf{2}}$ & OM & $\mathbf{N}$ & $\mathrm{Ca}$ & $\mathbf{M g}$ & $\mathbf{K}$ & Al \\
\hline & $\mathrm{Cm}$ & & Percent & Percent & $\begin{array}{c}M e / 100 \\
B^{2}\end{array}$ & $\begin{array}{l}M C c / 100 \\
\mathrm{~B}^{2}\end{array}$ & $\underset{g^{2}}{M e / 100}$ & $\begin{array}{c}M C e / 100 \\
B^{2}\end{array}$ \\
\hline Carreras (Aquic Tropohu- & $0-20$ & 5.0 & 4.88 & 0.14 & 6.10 & 0.86 & 0.32 & 1.54 \\
\hline $\begin{array}{l}\text { mult; clayey, kaolinitic, } \\
\text { isohyperthermic) }\end{array}$ & $33-43$ & 4.5 & 1.80 & .09 & 1.59 & .35 & .20 & 7.54 \\
\hline Los Guineos (Epiaquic Hu- & $0-15$ & 5.0 & 10.66 & .65 & 4.86 & 1.71 & .37 & 1.06 \\
\hline $\begin{array}{l}\text { moxic Tropohumult; } \\
\text { clayey, kaolinitic, iso- } \\
\text { thermic) }\end{array}$ & $17-35$ & 5.0 & 5.27 & .27 & 2.36 & .99 & .19 & 1.49 \\
\hline Piña (Psammentic Haplor- & $0-15$ & 5.3 & 1.81 & .07 & 1.00 & .18 & .08 & .37 \\
\hline $\begin{array}{l}\text { thox; sandy, isohyper- } \\
\text { thermic) }\end{array}$ & $20-40$ & 4.75 & 2.03 & .06 & .48 & .24 & .03 & 1.06 \\
\hline Catalina (Tropeptic Hap- & $0-12$ & 5.8 & 6.04 & .31 & 5.48 & .68 & .42 & 0 \\
\hline $\begin{array}{l}\text { lorthox; clayey, oxidic, } \\
\text { isohyperthermic) }\end{array}$ & $20-50$ & 5.4 & 3.60 & .22 & 3.72 & .88 & .64 & 0 \\
\hline $\begin{array}{l}\text { Nipe (Typic Acrorthox; } \\
\text { clayey, oxidic, isohyper- } \\
\text { thermic) }\end{array}$ & $\begin{array}{c}\text { Exposed } \\
\text { sub- } \\
\text { soil }\end{array}$ & 4.8 & 3.22 & .14 & 2.28 & 1.31 & .19 & 0 \\
\hline
\end{tabular}

1:2 soil: water.

2 Exchangeable $\mathrm{Ca}, \mathrm{Mg}$ and $\mathrm{K}$ with ammonium acetate; exchangeable $\mathrm{Al}$ with $1 \mathrm{~N}$ potassium chloride.

TABLE 2.-Available zinc, available phosphorus and phosphorus requirements of soils used

\begin{tabular}{|c|c|c|c|c|c|c|}
\hline \multirow[b]{2}{*}{ Soil } & & \multicolumn{3}{|c|}{ Available zinc } & \multirow[b]{2}{*}{$\mathbf{P}^{2}$} & \multirow[b]{2}{*}{$\begin{array}{c}\text { P require- } \\
\text { ments }\end{array}$} \\
\hline & & $\begin{array}{l}0.1 N \\
\mathrm{HC}\end{array}$ & Double' & $\frac{\text { DTPA" }}{\text { TEA }}$ & & \\
\hline & & $P \rho m$ & $P p m$ & $P p m$ & $P p m$ & $\mu g / g$ \\
\hline \multirow[t]{2}{*}{ Carreras } & Surface & 0.6 & 1.0 & 0.4 & 1.8 & $100-150$ \\
\hline & Sub & .4 & .7 & .1 & 4.2 & $440-480$ \\
\hline \multirow[t]{2}{*}{ Los Guineos } & Surface & 2.2 & 3.5 & 2.1 & 6.3 & $740-800$ \\
\hline & Sub & & .6 & & 1.8 & $650-700$ \\
\hline \multirow[t]{2}{*}{ Piña } & Surface & .6 & .8 & .3 & 133 & 0 \\
\hline & Sub & & & & 53.9 & 0 \\
\hline \multirow[t]{2}{*}{ Catalina } & Surface & 2 & 2.8 & 2.8 & 4.2 & - \\
\hline & Sub Site A & & 2 & & 1.4 & $640-860$ \\
\hline Nipe & Exposed subsoil & & & & 1.4 & $750-850$ \\
\hline
\end{tabular}

${ }^{1} 0.05 \mathrm{~N} \mathrm{HCl}$ plus $0.025 \mathrm{~N} \mathrm{H}_{2} \mathrm{SO}_{4}$.

20.005M diethylenetriaminepentaacetic acid, $0.01 M \mathrm{CaCl}_{2}$, and $0.1 M$ triethanolamine.

Available phosphorus by Bray No. 2.

- $\mathrm{Mg} P$ per $\mathrm{g}$ of soil necessary to obtain $0.2 \mathrm{ppm} P$ in equilibrium solution after 6 days by method of Fox and Kamprath (7). 
I. For the remaining experiments fiberglass wicks $27 \mathrm{~cm}$ long and $1.3 \mathrm{~cm}$ in diameter were used. ${ }^{5}$

All other pots were watered conventionally. They were brought to field capacity by sprinkling water on the surface one to three times daily.

Distilled water was used in all experiments except Experiment I.

In all experiments ammonium nitrate, potassium nitrate and monocalcium phosphate were used as sources of $N, P$, and $K$, except in Experiments III and IV, where potassium sulfate was used.

Split applications of nitrogen fertilizer through the growing period were made by injecting concentrated ammonium nitrate solution into the wicks with a hypodermic needle or adding it to the conventionally watered pots with irrigation water.

Ten to 12 seeds of maize (Zea mays L. cv. Pioneer Tropical Hybrid $\mathrm{X}$-306) were planted and thinned to 4 plants per pot. In some of the trials an effort was made to reduce fungus infection (especially severe in Carreras subsoil), by using seeds which had been germinated between moist paper towels.

The plants were grown in the greenhouse under natural light. After 2 to 3 weeks of growth (measured from the initiation of germination), plant tops were harvested, dried to constant weight at $70 \mathrm{C}$, and weighed.

\section{EXPERIMENT I}

This experiment was designed to sce if the soil productivity differences between Nipe subsoil and Carreras surface soil which were observed by Lathwell et al. (9) would persist at high phosphorus rates and continuous water supply.

\section{METHODS}

Treatments of 0,600 , and $1,800 \mathrm{ppm} \mathrm{P} \mathrm{(600} \mathrm{mixed} \mathrm{in} \mathrm{plus} 1,200$ spot placed) were applied to $2,000 \mathrm{~g}$ Nipe subsoil, and a treatment of $600 \mathrm{ppm}$ $\mathrm{P}$ was applied to $1,600 \mathrm{~g}$ Carreras surface soil. For spot placing, the monocalcium phosphate was divided into six parts. One part was placed in the center of the pot and the other five placed in 2-cm long glass tubes of 6 $\mathrm{mm}$ inside diameter and distributed around the pots at a depth of $6 \mathrm{~cm}$, in order to provide a concentrated phosphorus source with a minimum possibility of soil fixation. The soils were limed to pH 5.5 to 6.0. Each soil received $200 \mathrm{ppm} \mathrm{K}, 300 \mathrm{ppm} \mathrm{N}$ and a micronutrient solution supplying $10 \mathrm{ppm} \mathrm{Mn}$ as $\mathrm{MnCl}_{2} \cdot 4 \mathrm{H}_{2} \mathrm{O}, 5 \mathrm{ppm}$ Fe as sodium ferric diethylenetriamine

5 Type 4608, Atlas Asbestos Co., North Wales, Pa. Product and company name included for specific information only and does not imply any endorsement or preference for the product by the Agricultural Experiment Station of the University of Puerto Rico over other products not mentioned. 
pentaacetate, $2.4 \mathrm{ppm} \mathrm{B}$ as $\mathrm{H}_{3} \mathrm{BO}_{3}, 0.5 \mathrm{ppm} \mathrm{Cu}$ as $\mathrm{CuSO}_{4} \cdot 5 \mathrm{H}_{2} \mathrm{O}, 5 \mathrm{ppm}$ $\mathrm{Zn}$ as $\mathrm{ZnSO}_{4} \cdot 7 \mathrm{H}_{2} \mathrm{O}$ and $0.1 \mathrm{ppm} \mathrm{Mo}$ as $\mathrm{H}_{2} \mathrm{MoO}_{4} \cdot \mathrm{H}_{2} \mathrm{O}$.

To test the feasibility of using wick-watering methods and because the Nipe soil has a low available water content, two treatments using wickwatering were included: Nipe with $1,800 \mathrm{ppm} P$ and Carreras with 600 ppm P.

\section{RESULTS AND DISCUSSION}

The oven-dry weights of the plant tops which were harvested 24 days after planting are shown in table 3 . When water supply was adequate (wick-watering) and high amounts of phosphorus were added, the productivity of the Nipe subsoil equalled that of the Carreras surface soil.

TABLE 3.-Yield and foliar phosphorus content of maize grown on Nipe subsoil and Carreras surface soil at various phosphorus rates with conventional and wick walering in Experiment I

\begin{tabular}{lrlccc}
\hline \multicolumn{1}{c}{ Soil } & Applied P & \multicolumn{1}{c}{ Watering } & $\begin{array}{c}\text { Replica- } \\
\text { tions }\end{array}$ & Yield & Foliar P \\
\hline & $P p m$ & & & $g /$ pot & Percent \\
Nipe & 0 & Conventional & 4 & $2.72 \mathrm{a}$ & 0.12 \\
Nipe & 600 & Conventional & 4 & $10.42 \mathrm{~b}$ & .39 \\
Nipe & 1800 & Conventional & 4 & $10.48 \mathrm{~b}$ & .74 \\
Nipe & 1800 & Wick & 2 & $13.00 \mathrm{bc}$ & .45 \\
Carreras & 600 & Wick & 3 & $11.57 \mathrm{bc}$ & .54 \\
Carreras & 600 & Conventional & 4 & $12.82 \mathrm{c}$ & \\
\hline
\end{tabular}

1 Yields not followed by the same letter are significantly different at the 5-percent probability level according to Duncan's Multiple Range Test as modified by Kramer for unequal replication (11).

With Nipe the addition of $1,200 \mathrm{ppm}$ spot-placed phosphorus to the 600 ppm P mixed in had no effect on yield, but there was a considerable increase in phosphorus content of the leaves.

The previously reported low yields on Nipe subsoil in greenhouse experiments were probably due mainly to insufficient application of phosphorus. Phosphorus adsorption isotherm measurements [using the methods described by Fox and Kamprath (7)] showed that approximately $800 \mathrm{mg}$ $\mathrm{P} / \mathrm{g}$ of soil were necessary to maintain an equilibrium solution concentration of $0.2 \mathrm{ppm} \mathrm{P} \mathrm{(table} \mathrm{2),} \mathrm{regarded} \mathrm{as} \mathrm{sufficient} \mathrm{for} \mathrm{plant} \mathrm{growth} \mathrm{in} \mathrm{pots.}$ In this experiment $600 \mathrm{ppm}$ apparently provided sufficient $P$ in the pots, as $1,800 \mathrm{ppm}$ gave no higher yiclds.

The rates of $\mathrm{P}$ applied to satisfy phosphorus requirements of plants grown in pots are far higher than those necessary in the field. Baker and Woodruff (2) observed in pot experiments with maize that a dispropor- 
tionately large increase in rates of $P$ fertilization was necessary as pot size was decreased. Fox and Kamprath (7) attributed this to interception of plant roots by the container walls causing "piling-up" of the roots which results in reducing their effectiveness for phosphorus uptake. Because of this observed amplification of $P$ requirements in pots, one can expect to reach plateau levels of $P$ response in the field with much lower levels of $P$ fertilization than were necessary here.

Use of the automatic wick-watering method to maintain a continuous supply of easily available water did not significantly increase the yield in the fertilized Nipe.

\section{EXPERIMENT II}

In a nitrogen experiment described by Fox (6), marked differences in productivity at the same level of nitrogen had been observed on different areas of a field of Carreras soil. It appeared that yields decreased as the amount of subsoil mixed in with the surface soil increased.

A preliminary experiment on surface soils, a partially exposed cropped subsoil, and a subsoil from the field showed that the yield relationship observed in the field could be reproduced in the greenhouse. All the soils received $300 \mathrm{ppm} \mathrm{N}, 300 \mathrm{ppm} \mathrm{P,} 200 \mathrm{ppm} \mathrm{K}, 50 \mathrm{ppm} \mathrm{Mg}$ and the micronutrients described in Experiment I. The yield on the subsoil was only 69 percent of the yield on the surface soil. Yields were proportional to both soil organic matter content and Bray No. 2 available P. In the preliminary experiment the addition of 2 percent organic matter in the form of dried, partially decomposed coffee leaves increased yields on the subsoil by 18 percent. Foliar analysis indicated that $\mathrm{Mg}, \mathrm{Zn}$, and $\mathrm{P}$ might be insufficient.

Experiment II was carried out to see if the reduction in productivity of the Carreras subsoil could be eliminated with mineral amendments or if organic matter additions were also necessary.

\section{METHODS}

Three levels of phosphorus $(100,200$, and $300 \mathrm{ppm} P$ ) were applied to $1,600 \mathrm{~g}$ Carreras subsoil receiving zero or $36 \mathrm{ppm} \mathrm{Zn}$. An additional treatment receiving $300 \mathrm{ppm} \mathrm{P}, 36 \mathrm{ppm} \mathrm{Zn}$ and 1 percent ground, dried, partially decomposed coffee leaves was included. For comparison, Carreras surface soil with and without added $\mathrm{Zn}$ was included. All soils were limed to $\mathrm{pH} 5.1$ to 5.5, fertilized with $300 \mathrm{ppm} \mathrm{N}$ and $200 \mathrm{ppm} \mathrm{K}$, and all but Treatment 10 received $100 \mathrm{ppm} \mathrm{Mg}$ as magnesium sulfate. Three replicates per treatment, all wick-watered, were arranged in Random Complete Blocks, and the experiment was harvested 24 days after the initiation of germination. 


\section{RESULTS AND DISCUSSION}

The results (shown in table 4 and fig. 1) indicate that when $300 \mathrm{ppm}$ $\mathrm{P}$ and $36 \mathrm{ppm} \mathrm{Zn}$ were added to the subsoil, the yield was as high as that obtained on surface soil with $\mathrm{Zn}$ or on subsoil plus organic matter. Apparently $5 \mathrm{ppm} \mathrm{Zn}$, as supplied by the micronutrient solution used in the preliminary experiment, was not sufficient. The response to $\mathrm{Zn}$, particularly at high phosphorus level, was striking, exceeding 100 percent (fig. 1). There was also a marked response to the application of $\mathrm{Zn}$ in the surface soil. It is clear that both $\mathrm{Zn}$ and $\mathrm{P}$ are needed to maximize yields in Carreras surface and subsoil.

TABLE 4.-Trealments and yields on Carreras surface and subsoils in Experiment II

\begin{tabular}{|c|c|c|c|c|}
\hline \multirow{2}{*}{ Treatment number } & \multicolumn{3}{|c|}{ Treatment } & \multirow{2}{*}{ Yieldי } \\
\hline & $\mathbf{Z n}$ & $\mathbf{P}$ & $\mathrm{Cu}$ & \\
\hline & $P p m$ & $P p m$ & $P p m$ & $g / p o t$ \\
\hline \multicolumn{5}{|l|}{ Subsoil } \\
\hline 1 & 0 & 100 & 21 & $4.60 \mathrm{a}$ \\
\hline 2 & 0 & 200 & 21 & $5.60 a$ \\
\hline 3 & 0 & 300 & 21 & $6.97 \mathrm{a}$ \\
\hline 4 & 36 & 100 & 21 & $6.63 a$ \\
\hline 5 & 36 & 200 & 21 & $11.23 \mathrm{~b}$ \\
\hline 6 & 36 & 300 & 21 & $14.23 \mathrm{bc}$ \\
\hline $7^{2}$ & 36 & 300 & 21 & $13.33 \mathrm{bc}$ \\
\hline 8 & 36 & 300 & 0 & 15.27 \\
\hline \multicolumn{5}{|l|}{ Surface soil } \\
\hline 9 & 0 & 300 & 21 & $7.70 a$ \\
\hline 10 & 36 & 300 & 21 & $14.30 \mathrm{~b}$ \\
\hline
\end{tabular}

1 Yields not followed by the same letter are significantly different at the 5-percent probability level by the Duncan's New Multiple Range Test.

2 Plus 1-percent coffee leaves.

The subsoil showed no significant response to added $\mathrm{Cu}$ nor to the addition of 1 percent dried ground partially decomposed coffee leaves when adequate $\mathrm{Zn}$ and $\mathrm{P}$ were present.

The results of foliar analysis are shown in table 5. These emission spectroscopy measurements were unreplicated so the possibility of error cannot be eliminated. The phosphorus content was erratic in the zinc-deficient plants but in the zinc-sufficient treatments $P$ content increased with applied phosphorus to 0.30 percent $P$ at $300 \mathrm{ppm} P$ added, which is within the sufficient range for maize according to Jones (8). Zinc content was deficient at all levels of phosphorus when no zinc was applied, but when 36 ppm $\mathrm{Zn}$ was applied the plant zinc content was sufficient in the 200 and 300 ppm $P$ treatments. 


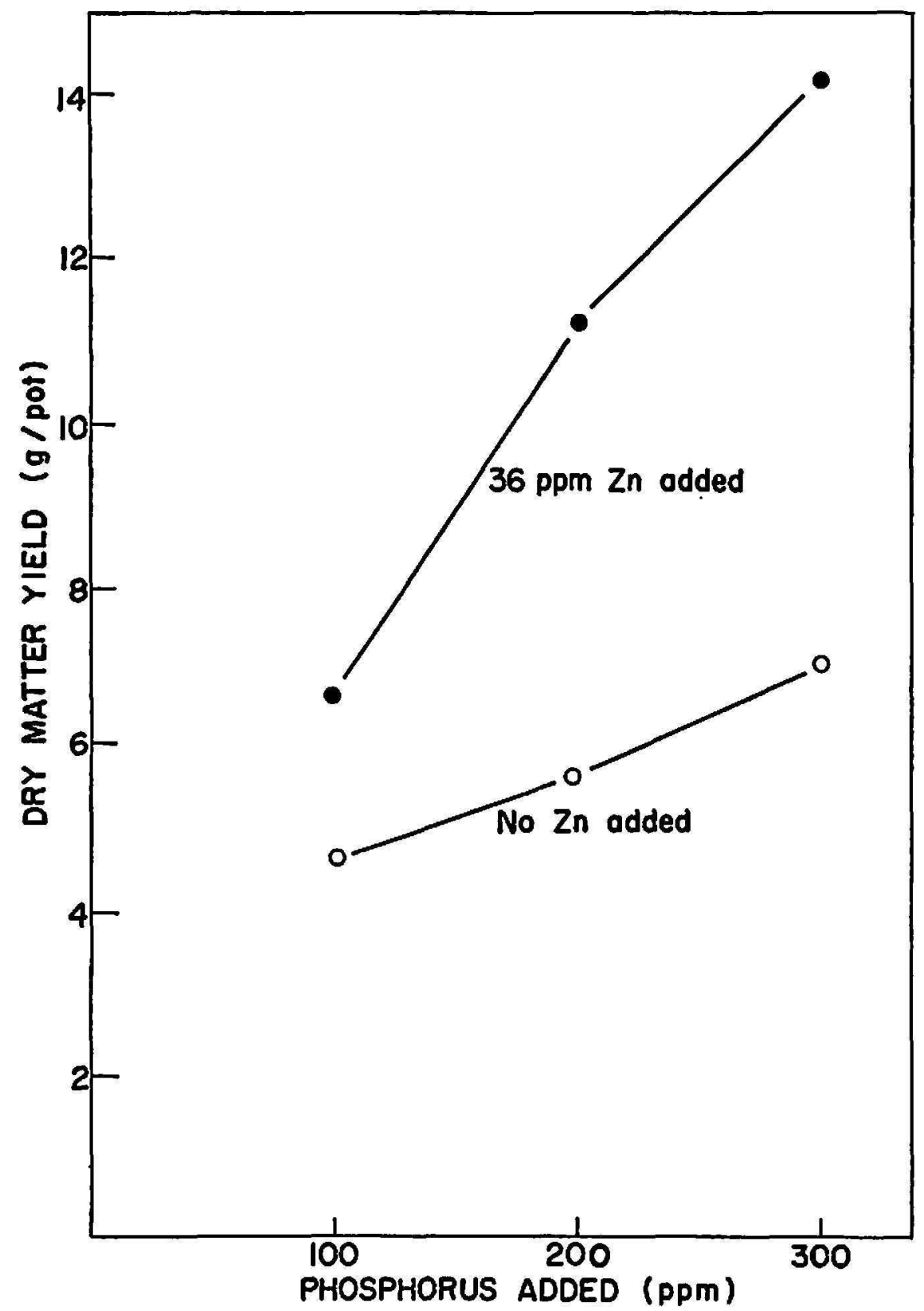

Fro. 1,-Relationship between phosphorus application and dry matter yield of maize with and without added zinc.

In spite of the addition of $100 \mathrm{ppm} \mathrm{Mg}$ as magnesium sulfate the magnesium content was unusually low in all the subsoil treatments. The plants from the highest yielding treatment, No. 8, contained 0.04 percent $\mathrm{Mg}$ which is in the deficiency range for maize according to Jones (8). At these low levels of $\mathrm{Mg}$, however, the results of emission spectroscopy are not extremely accurate because the precision of the instrument is only \pm 0.02 percent for $\mathrm{Mg}$. Unusually low magnesium contents in Pioneer X-306 maize growing in field plots have been observed by the authors and other workers in Puerto Rico (F. Abruña, personal communication). 


\section{EXPERIMENT III}

The differences in productivity thus far tested had disappeared completely with sufficient mineral fertilization. In an effort to find additional cases where a marked difference in productivity existed, the following were compared: Surface and subsoil of Los Guineos (Epiaquic Humoxic Tropohumult); surface soil of Carreras (Aquic Tropohumult); surface and subsoil of Piña (Psammentic Haplorthox); and surface and two subsoils of Catalina (Typic Haplorthox).

TABLE 5.-Foliar analyses of maize planls from Experiment II

\begin{tabular}{|c|c|c|c|c|c|c|c|c|c|c|c|c|c|}
\hline $\begin{array}{l}\text { Treat- } \\
\text { ment } \\
\text { number }\end{array}$ & Yield & $\mathbf{N}$ & $\mathbf{P}$ & K & $\mathrm{Ca}$ & $\mathbf{M g}$ & $\mathbf{M n}$ & Fe & B & $\mathrm{Cu}$ & $z_{n}$ & Al & Mo \\
\hline & s/pot & $\begin{array}{l}\text { Per- } \\
\text { cent }\end{array}$ & Percen $l$ & Percent & Percent & Percenl & $P p m$ & $P p m$ & $P p m$ & $P p m$ & $P \mathrm{pm}$ & $P p m$ & $P p m$ \\
\hline 1 & 4.60 & 2.9 & 0.12 & 4.69 & 0.65 & 0.05 & 69 & 57 & 8 & 7 & 8 & 62 & 2.1 \\
\hline 2 & 5.60 & 3.5 & .31 & 4.70 & 1.36 & .17 & 106 & 106 & 15 & 19 & 10 & 84 & 2.2 \\
\hline 3 & 6.97 & 3.2 & .20 & 5.79 & .52 & .04 & 51 & 41 & 9 & 4 & 7 & 44 & 1.8 \\
\hline 4 & 6.63 & 2.7 & .09 & 3.86 & .25 & $<0.01$ & 21 & 36 & 5 & 3 & 12 & 53 & 1.7 \\
\hline 5 & 11.23 & 2.3 & .19 & 3.77 & .62 & .06 & 57 & 93 & 15 & 12 & 56 & 71 & 2.1 \\
\hline 6 & 14.23 & 2.0 & .30 & 3.39 & .35 & .04 & 41 & 69 & 13 & 10 & 46 & 48 & 2.1 \\
\hline 8 & 15.27 & 2.1 & .21 & 3.43 & .46 & .04 & 46 & 72 & 12 & 9 & 54 & 48 & 1.8 \\
\hline 9 & 7.70 & 2.9 & .34 & 2.73 & .75 & .29 & 119 & 236 & 14 & 19 & 13 & 64 & 1.8 \\
\hline 10 & 14.30 & 2.5 & .24 & 1.61 & .34 & .12 & 40 & 98 & 12 & 11 & 46 & 57 & 2.1 \\
\hline
\end{tabular}

\section{METHODS}

The basic fertilizer treatment applied to each soil $(1,600 \mathrm{~g}$ per pot) included $\mathrm{Zn}$ where a zinc deficiency was suspected, $270 \mathrm{ppm} \mathrm{N}, 200 \mathrm{ppm} \mathrm{K}$ and 350 to $400 \mathrm{ppm} P$ (table 6). Piña surface and subsurface soil $(2,000 \mathrm{~g}$ per pot) received $320 \mathrm{ppm} \mathrm{N}$ and $200 \mathrm{ppm} \mathrm{K}$ but no P. No blanket micronutrient treatment was applied. Where necessary, soils were limed to a $\mathrm{pH}$ between 5.1 and 5.7 with an equimolar mixture of magnesium and calcium hydroxides. Two watering regimes were used to ensure adequate water supply. Three wick-watered and three conventionally watered pots per treatment were arranged in a Completely Random Design.

Because of the variable emergence due to inadequate initial watering of the soil, the plants were harvested 13 days after the average plant height per pot reached $13.2 \mathrm{~cm}$ (20 to 22 days after the initiation of germination). At harvest the plants were 50 to $71 \mathrm{~cm}$ high. This procedure allowed growth rate to be measured and eliminated the effect of initial emergence differences. 


\section{RESULTS AND DISCUSSION}

Table 6 shows that all the soils in this survey except Catalina subsoil at site $A$ and Catalina subsoil at site $B$ produced yields which were within 15 percent of, and not significantly different from, the Los Guineos surface soil yield (which was the highest yielding), under the watering regime most effective for that soil. The yields from the wick-watering method replicates were as good or better than those on the conventionally watered pots except on the Carreras surface soil, where low hydraulic conductivity

TABLE 6.-Watering melhod, ferlilizer trealment and yield of maize on eight soils surveyed in Experiment III

\begin{tabular}{|c|c|c|c|c|c|c|}
\hline \multirow{2}{*}{ Soil } & & \multirow{2}{*}{ Watering } & \multicolumn{3}{|c|}{ Treatment } & \multirow{2}{*}{ Yield" } \\
\hline & & & $\mathbf{P}$ & $\mathbf{Z n}_{\mathbf{n}}$ & Lime' & \\
\hline & & & $P p m$ & $P p m$ & $P p m$ & g/pot \\
\hline \multirow[t]{2}{*}{ Los Guineos } & Surface & Wick & 350 & $\mathbf{0}$ & 1906 & 15.33 \\
\hline & & Conventional & 350 & 0 & 1906 & 12.73 \\
\hline \multirow[t]{2}{*}{ Carreras } & Surface & Conventional & 400 & 18 & 1119 & 14.73 \\
\hline & & Wick & 400 & 18 & 1119 & $11.27 \mathrm{abcd}$ \\
\hline \multirow[t]{2}{*}{ Piña } & Surface & Conventional & 0 & 18 & 241 & 14.00 efg \\
\hline & & Wick & 0 & 18 & 241 & 13.30 \\
\hline \multirow[t]{2}{*}{ Los Guineos } & Sub & Wick & 400 & 18 & 1906 & 13.67 \\
\hline & & Conventional & 400 & 18 & 1906 & $9.30 \mathrm{a}$ \\
\hline \multirow[t]{2}{*}{ Piña } & Sub & Wick & 0 & 18 & 393 & 13.37 defg \\
\hline & & Conventional & 0 & 18 & 393 & $10.43 \mathrm{abc}$ \\
\hline \multirow[t]{2}{*}{ Catalina } & Surface A & Wick & 400 & 0 & 0 & 13.07 defg \\
\hline & & Conventional & 400 & 0 & 0 & 12.87 \\
\hline \multirow[t]{2}{*}{ Catalina } & Sub B & Wick & 400 & 0 & 1184 & 12.63 cdef \\
\hline & & Conventional & 400 & $\mathbf{0}$ & 1184 & 11.67 bcde \\
\hline \multirow[t]{2}{*}{ Catalina } & Sub A & Wick & 400 & 0 & 659 & $9.80 \mathrm{a}$ \\
\hline & & Conventional & 400 & 0 & 659 & $9.17 \mathrm{a}$ \\
\hline
\end{tabular}

1 Equimolar mixture of magnesium hydroxide and calcium hydroxide.

2 Yields not followed by the same letter are significantly different by Duncan's New Multiple Range Test.

at low moisture contents may have reduced the availability of water during high transpiration periods.

\section{EXPERIMENT IV}

\section{TRIAL ONE}

A further experiment was made comparing the lowest and highest yielding of the eight soils surveyed in the previous experiment.

\section{Methods}

Four levels $(0,300,300$ banded, and $600 \mathrm{ppm})$ of phosphorus were applied to $1,600 \mathrm{~g}$ of the lowest yielding, the Catalina subsoil location $\mathrm{A}$. 
Since the Catalina subsoil had not previously received any zinc, $36 \mathrm{ppm}$ $\mathrm{Zn}$ were added to each treatment. Two levels of phosphorus (300 and 600 ppm) were applied to the highest-yielding soil of the previous trial, the Los Guineos surface soil, to see if phosphorus fertilization was optimal. The soils were limed with an equimolar mixture of $\mathrm{Ca}(\mathrm{OH})_{2}$ and $\mathrm{Mg}(\mathrm{OH})_{2}$ to $\mathrm{pH} 5.4$ to 5.7 , and received $360 \mathrm{ppm} \mathrm{N}$ and $100 \mathrm{ppm} \mathrm{K}$. All were wickwatered. The plant tops were harvested 23 days after planting.

Results and Discussion

Table 7 presents the results of the comparison at higher $P$ rates of the highest and lowest yielding soils of the previous experiment. Yields on both soils still exhibited a strong response to phosphorus. Banding the 300

TAane 7.-Trealments and yields of maize on Catalina subsoil and Los Guineos surface soil in Experiment IV, Trial One

\begin{tabular}{|c|c|c|c|c|c|}
\hline \multirow{2}{*}{ Soil } & \multirow{2}{*}{$\begin{array}{l}\text { Number } \\
\text { of } \\
\text { replicates }\end{array}$} & \multicolumn{2}{|c|}{ Treatment } & \multirow{2}{*}{\multicolumn{2}{|c|}{ Yield² }} \\
\hline & & $\mathbf{P}$ & $\mathbf{Z n}$ & & \\
\hline \multirow{5}{*}{ Catalina subsoil } & & $P p m$ & $P p m$ & $g / p o t$ & \\
\hline & 3 & $\mathbf{0}$ & 36 & $3.20 \mathrm{a}$ & \\
\hline & 3 & 300 & 36 & 12.57 & \\
\hline & 3 & $300^{1}$ & 36 & $13.33 \mathrm{k}$ & 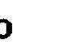 \\
\hline & 3 & 600 & 36 & 16.77 & c \\
\hline \multirow[t]{2}{*}{ Los Guineos surface soil } & 4 & 300 & 18 & 16.90 & c \\
\hline & 4 & 600 & 18 & 21.15 & d \\
\hline
\end{tabular}

1 Phosphorus was banded.

2 Yields not followed by the same letter are significantly different at the 5-percent probability level according to Duncan's New Multiple Range Test as modified by Kramer for unequal replication (11).

ppm phosphorus application was no more effective than mixing. The yield of Catalina subsoil receiving $600 \mathrm{ppm}$ was almost identical to that of the Los Guineos surface soil receiving $300 \mathrm{ppm} P$, but significantly less than the Los Guineos with $600 \mathrm{ppm}$ P.

\section{TRIAL TWO}

Results of the previous trial indicated that yields on both soils were still responding to phosphorus applications.

\section{Methods}

Another trial was therefore run, as part of a larger experiment, using the same soils, which were dried, pooled, and repotted after the addition of $205 \mathrm{ppm} \mathrm{K}$ and $47 \mathrm{ppm} \mathrm{Mg}$ to the Catalina subsoil and $226 \mathrm{ppm} \mathrm{K}$ and $52 \mathrm{ppm} \mathrm{Mg}$ to the Los Guineos surface soil. Two levels of additional phosphorus were applied to each soil (566 ppm and 1,132 ppm to the Catalina 
subsoil and $520 \mathrm{ppm}$ and $1,025 \mathrm{ppm}$ to the Los Guineos surface soil). The $520 \mathrm{ppm} P$ treatment Catalina subsoil also received $0.6 \mathrm{ppm}$ B. Each treatment consisted of four replicates, all of which were wick-watered.

\section{Results and Discussion}

Results of this trial, given in table 8 , showed that response to phosphorus in both soils was now at or near plateau level, and that the yields on the two soils were not significantly different.

This demonstrated that the previously low subsoil yield could be brought to the level of a highly fertile surface soil by the addition of phosphorus and zinc.

TABLE 8.-Treatment and yield of maize on Catalina subsoil location $F$ and Los Guineos surface soil in Experiment IV, Trial Two

\begin{tabular}{ccc}
\hline Soil & P added & Yields \\
\hline & $P p m$ & $8 /$ pot \\
Catalina subsoil Site A & 520 & $20.22 \mathrm{a}$ \\
& 1025 & $20.70 \mathrm{a}$ \\
Los Guineos surface soil & 566 & $20.74 \mathrm{a}$ \\
& 1132 & $21.59 \mathrm{a}$
\end{tabular}

1 Yields followed by the same letter are not significantly different at the 5-percent probability level according to Duncan's New Multiple Range Test.

\section{CONCLUSION}

This study shows that differences in productivity of soils observed in previous experiments were not due to inherent limitations of the subsoils, but arose because of their higher requirements for phosphorus, zinc and available water.

As the requirements of mechanized agriculture increase the amount of land-leveling and subsequent exposure of subsoils in the Tropics, there is a growing need to be able to obtain maximum yields on these soils. The results of this study indicate that with careful water management, liming and fertilization (with $\mathbf{P}$ and $\mathrm{Zn}$ especially) the Oxisol and Ultisol surface and subsoils tested can all be equally productive. It will be necessary to conduct field experiments to determine how high the rates of $\mathrm{P}$ fertilization must be to reach near-maximum yields but it can be assumed it will be less than the $1000 \mathrm{ppm} P$ required in the greenhouse pots.

\section{SUMMARY}

Greenhouse experiments with maize were carricd out to see if the reported infertility of some subsoils could be improved with mineral fertilization and efficient watering. 
It was shown that the Nipe soil series (Typic Acrorthox; clayey, oxidic, isohyperthermic) exposed subsoil was as productive as the Carreras series (Aquic Tropohumult; clayey, kaolinitic, isohyperthermic) surface soil when $\mathrm{N}, \mathrm{K}$, micronutrients and $600 \mathrm{ppm} P$ were added and the pots were watered by means of wicks.

Carreras subsoil, when limed and fertilized with N, K, 300 ppm P, 100 ppm $\mathrm{Mg}$ and $36 \mathrm{ppm} \mathrm{Zn}$ produced as well as Carreras surface soil, even though it contained only about one-third as much organic matter.

A comparison among eight surface and subsoils showed that yields on limed, liberally fertilized, well-watered Los Guineos series (Epiaquic Humoxic Tropohumult; clayey, kaolinitic, isothermic) surface soil, Carreras surface soil, Piña series (Psammentic Haplorthox; sandy, isohyperthermic) surface soil, Los Guineos subsoil, Piña subsoil and Catalina series (Tropeptic Haplorthox; clayey, oxidic, isohyperthermic) surface soil were not signifcantly different. However, the yield on the least productive of two Catalina subsoils was only 64 percent of the yield on the Los Guineos surface soil. But with the addition of $\mathrm{Zn}$ and slightly over $1,000 \mathrm{ppm} \mathrm{P}$, greenhouse pot yields on the two soils were essentially the same. Field experiments will be necessary to determine optimum $P$ rates under field conditions.

It was concluded that the productivity in greenhouse pots of surface and subsoils of the Ultisols and Oxisols studied can all be brought to the same high level, provided adequate mineral fertilization (including $\mathbf{Z n}$ and high $P$ rates), lime and water management are used.

\section{RESUMEN}

Para comprobar si es posible corregir mediante el abonamiento y el riego adecuado la infertilidad que se ha informado respecto a algunos subsuelos, se llevaron a cabo experimentos con maiz en un invernadero.

Se encontró que el subsuelo expuesto de un suelo de la serie Nipe (Acrorthox típico; arcilloso, oxídico e isohipertérmico) era tan productivo como un suelo superficial de la serie Carreras (Tropohumult ácuico; arcilloso, caolinítico e isohipertérmico) cuando se le añadieron $N, K$, elementos menores y 600 ppm de $P, y$ los tiestos se regaron por medio de mechas.

El subsuelo Carreras, cuando se encaló y se abonó con N, K, 300 ppm de P, 100 ppm de $\mathrm{Mg}$ y $36 \mathrm{ppm}$ de $\mathrm{Zn}$ fue tan productivo como la capa superficial, a pesar de contener solo una tercera parte de la materia orgánica.

En un estudio comparativo entre ocho suelos superficiales y subsuelos se observó que los rendimientos de un suelo superficial encalado, bien abonado y regado adecuadamente de la serie Los Guineos (Tropohumult epiácuico humb́xico; arcilloso, caolinítico e isotérmico); uno superficial de la serie Carreras; otro superficial de la serie Piña (Haplorthox psaméntico; arenoso e isohipertérmico); un subsuelo Los Guineos; otro subsuelo de la serie Piña; y uno superficial de la serie Catalina (Haplorthox tropéptico; arcilloso, oxídico e isohipertérmico) no eran significativamente diferentes. Sin embargo, el rendimiento del menos productivo de los dos subsuelos Catalina solo fue 64 por ciento del rendimiento del suelo superficial Los Guineos. 
Pero al añadírsele $Z n$ y un poco más de $1,000 \mathrm{ppm}$ de $\mathrm{P}$, el rendimiento de ambos suelos en invernadero fue casi igual. Para determinar la cantidad óptima de $\mathrm{P}$ que debe aplicarse en condiciones de campo será necesario llevar a cabo experimentos de campo.

Se concluyó que la productividad de los suelos superficiales y los subsuelos de los Ultisoles y Oxisoles que se estudiaron en tiestos en invernadero puede elevarse al mismo nivel alto si se abonan con minerales (incluyendo $\mathrm{Zn}$ y aplicaciones elevadas de $P$ ), se encalan y se riegan adecuadamente.

\section{LITERATURE CITED}

1. Abruña-Rodriguez, F., Vicente-Chandler, J., Pearson, R. W., and Silva, S., Crop response to soil acidity factors in Ultisols and Oxisols: I. Tobacco, Soil Sci. Soc. Amer. Proc. 34: 629-35, 1970.

2. Baker, D. E., and Woodruff, C. F., Influence of volume of soil per plant upon growth and uptake of phosphorus by corn from soils treated with different amounts of phosphorus, Soil Sci. 94: 409-12, 1963.

3. Cornell University, Dep. of Agron., Annual Summary Progress Report for July 1, 1969 to June 30, 1970, submitted to the U.S. Agency for International Development under contract AID/csd 2490 entitled "Soil Fertility Requirements to Attain Efficient Production of Food Crops on the Extensive, Deep, WellDrained but Relatively Infertile Acid Soils of the Humid Tropics," 1970.

4. Cornell University, Department of Agronomy, Annual Summary Progress Report for July 1, 1970 to June 30, 1971, submitted to the U.S. Agency for International Development under contract AlD/csd 2490 entitled "Soil Fertility Requirements to Attain Efficient Production of Food Crops on the Extensive, Deep, Well-Drained but Relatively Infertile Acid Soils of the Humid Tropics," 1971.

5. Dolar, S. G., and Keeney, D. R., A self-watering system for growing plants in potted soils, Agron. J., 63: 334-5, 1971.

6. Fox, R. H., Nitrogen fertilization in the Humid Tropics, Cornell Univ. Agron Mimeo 72-17, Cornell Univ. Ithaca, N.Y., 1972.

7. Fox, R. L., and Kamprath, E. J., Phosphate sorption isotherms for evaluating the phosphate requirements of soils, Soil Sci. Soc. Amer. Proc. 34: 902-5, 1970.

8. Jones, J. B., Jr., Interpretation of plant analysis for several agronomic crops, In Stelly, M., (ed.), Soil testing and plant analysis, Part II, Plant analysis, SSSA Spec. Pub. Series, pp. 49-58, 1967.

9. Lathwell, D. J., Dubey, H. D., and Fox, R. H., Nitrogen-supplying power of some tropical soils of Puerto Rico and methods for its evaluation, Agron. J. 64: 763-7, 1972.

10. Ritchey, K. D., and Fox, R. H., Use of wick-watering for greenhouse pots in the Tropics (submitted for publication in Trop. Agr.). 